\title{
EVALUATION OF MORAL INTELLIGENCE OF HEALTHCARE PROFESSIONALS VIA THE "SURVEY FOR MEASURING MORAL INTELLIGENCE IN THE PROVISION OF HEALTHCARE SERVICES"
}

\begin{abstract}
Hulya Ozturk ${ }^{1}$, Omur Sayligil², Zeki Yildiz ${ }^{3}$
Abstract: Moral intelligence -through which an individual makes mental evaluation before taking action about a decision- is important in individual-centered healthcare. Using Lawshe Method, we designed the "Survey for Measuring Moral Intelligence in the Provision of Healthcare Services" with "equality", "empathy", "moral intelligence", "justice", "tolerance", "self-control", and "politeness" dimensions ( $\alpha=.966)$. Age of the population (physicians and nurses) was $36.44 \pm 9.52$, consisting $517(65.5 \%)$ women, 538 married participants, 653 employed in public hospitals, and 352 had work experience of $<10$ years. All participants were moral intelligence-sensitive. Those who had children, worked in a private organization, and had longer work experience were more sensitive with regard to "equality", which varied by marital status, frequency of working outside normal working hours, and age groups. "Politeness" varied between participants that have worked for $>8$ hours/day. Using dimensions of this survey as skills is expected to ensure due diligence about rights and dignity in healthcare services.
\end{abstract}

Keywords: moral intelligence, clinical ethics, healthcare

Evaluación de la inteligencia moral de profesionales de la salud a través de la "Encuesta para medir la inteligencia moral en la prestación de servicios de salud"

La inteligencia moral, mediante la cual un individuo realiza una evaluación mental antes de tomar medidas sobre una decisión, es importante en la atención médica centrada en el individuo. Usando el método Lawshe, diseñamos la "Encuesta para medir la inteligencia moral en la provisión de servicios de salud" con dimensiones de "igualdad", "empatía", "inteligencia moral",

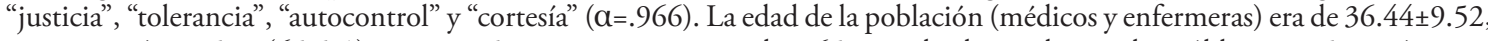
que consistía en $517(65,5 \%)$ mujeres, 538 participantes casados, 653 empleados en hospitales públicos y 352 tenían una experiencia laboral de $<10$ ańos. Todos los participantes eran sensibles a la inteligencia moral. Los participantes que tenían hijos trabajaban en una organización privada, y los que tenían una experiencia laboral más larga eran más sensibles respecto de la "igualdad", que variaba según el estado civil, la frecuencia de trabajo fuera del horario normal de trabajo y los grupos de edad. La "cortesía" varió entre los participantes que han trabajado durante $>8$ horas/día. Se espera que el uso de las dimensiones de esta encuesta como habilidades garantice la debida diligencia sobre los derechos y la dignidad en los servicios de atención médica.

Palabras clave: inteligencia moral, ética clínica, atención médica

Avaliaçáo da inteligência moral de professionais de saúde via "Levantamento para Medir a Inteligência Moral na Provisáo de Serviços de Cuidados à Saúde"

Resumo: Inteligência moral —através da qual um individuo faz uma avaliação mental antes de agir frente a uma decisão- é importante em cuidados à saúde centrados na pessoa. Usando o Método Lawshe, nós elaboramos o "Levantamento para Medir a Inteligência Moral na Provisão de Serviços de Cuidados à Saúde" com as dimensóes "igualdade", "empatia", "inteligência moral", "justiça", "tolerância", "autocontrole" e "polidez $(\alpha=.966)$. A idade da população (médicos e enfermeiras) foi $36.44 \pm 9.52$ anos, consistindo de 517 (65.5\%) mulheres, 538 participantes casados, 653 empregados em hospitais públicos e 352 tinham experiência de trabalho $<10$ anos. Todos os participantes eram sensíveis à inteligência moral. Os que tinham crianças trabalhavam em organização privada e tinham mais anos de experiência de trabalho, eram mais sensíveis com respeito à "igualdade", que variava em função do estado civil, frequência de trabalho fora do horário normal e faixas etárias. "Polidez" variou entre participantes que tinham trabalhado por $>8$ horas/dia. Usando dimensôes deste levantamento como habilidades, espera-se que garanta a devida presteza sobre direitos e dignidade em serviços de cuidados à saúde.

Palavras chave: inteligência moral, ética clínica, cuidados à saúde

\footnotetext{
${ }^{1}$ Eskisehir Osmangazi University, History of Medicine and Ethics, Eskisehir Turkey. ORCID: 0000-0001-8999-4213 Correspondence: hulyaozturk33b@gmail.com

${ }^{2}$ Eskisehir Osmangazi University, History of Medicine and Ethics, Eskisehir Turkey. ORCID: 0000-0001-7517-7503

${ }^{3}$ Eskisehir Osmangazi University, Department of Statistics, Eskisehir Turkey. ORCID: 0000-0003-1907-2840
} 


\section{Introduction}

Moral intelligence has so far been defined as "the capacity to understand right from wrong", as "the mental capacity to determine how universal human principles should be applied to our values, goals, and actions" $(1,2)$ and as a type of intelligence that focuses on impelling professionals and experts to use some skills in the business world(3).

M. Borba defined seven parameters of moral intelligence, i.e. empathy, respect, fairness, politeness, tolerance, self-control, and conscience; and Lennick and Kiel defined four parameters, i.e. integrity, responsibility, compassion, and forgiveness $(2,4)$.

Medical practices are, by their nature, intermingled with value problems. There is a need for medical ethics at this point. Limitations, playing a central role in showing goodwill and using knowledge, are required by healthcare professionals to manage any ambiguities and decision-making processes $(2,5,6)$.

Healthcare requires not only technical knowledge but also effective communication skills from providers. Healthcare professionals are required make a holistic assessment of patients rather than focus only on disorders to obtain better results from treatment. Patients are able to express themselves more explicitly and clearly when healthcare professionals empathize with and show respect to patients, approach them with sense of justice, and are more tolerant, conscientious and polite $(2,5,6)$.

Patient satisfaction is likely to increase when healthcare professionals communicate with patients using moral intelligence parameters in diagnosis and treatment.

\section{Participants and methods}

2.1. Type of research: This study was conducted to find out viewpoints on moral intelligence and its parameters of healthcare professionals employed in Eskişehir.

2.2. Population and sample of research: Physicians and nurses employed in Eskişehir were invited to participate in this study. A sampling method was used to save time and reduce costs. Stratified sampling was used to ensure that participants with various sociocultural and socioeconomic background were represented in the stu$\mathrm{dy}(7)$. The sample size was calculated by taking into consideration the total number of physicians and nurses working in public and private hospitals in Eskişehir.

Total Number of Physicians in Eskişehir: 1469

Total Number of Nurses in Eskişehir: 1989

Sample size for physicians: 305 (384 considering an attrition rate of $25 \%$ )

Sample size for nurses: 322 (405 considering an attrition rate of $25 \%$ )

About 1000 volunteers received and replied the survey from. Data from 789 professionals that replied all questions in the survey were used in this study.

\subsection{Data-collecting instruments and method:}

The review of literature showed that there was no survey to measure moral intelligence and its parameters in the field of healthcare. Thus, this study set out to develop a new survey considering that characteristics of moral intelligence parameters - equality, empathy, conscience, justice, tolerance, self-control and politeness - differ from one culture to another and are of particular importance in the provision of healthcare services. C. H. Lawshe method was used to develop the survey $(8,9)$.

The survey developed for the purpose of this study consists of two parts. The first part (Socio-demographic Survey Form) comprises ten questions regarding healthcare professionals' socio-demographic characteristics. The second part seeks healthcare professionals' opinions on moral intelligence parameters. All individual items in the survey were designed in the form of 5-point Likert statements (1-Strongly disagree,2-Disagree,3-Partially agree,4-Agree,5-Strongly agree). The Eigenvalues and the percentage of variance explained in the Exploratory Factor Analysis (EFA) results suggest that the "Survey for Measuring Moral Intelligence in the Provision of Healthcare Services" con- 
sists of 47 items and 7 factors.

Confirmatory Factor Analysis (CFA) was performed on LISREL 8.80 in order to test how well the predefined construct was consistent with data collected in the study(10-12). In CFA, primarily, $t$ values that indicate the significance of parameter estimates related to paths in the model are tested in order to determine whether a theoretical model is statistically significant and adequate. A $t$ value greater than 1.96 is required for significance at 0.05 , and greater than 2.58 is required for significance at 0.01 . For 47 items of the scale, $t$ values were greater than 1.96 and thus significant $(11,12)$. According to EFA and CFA results, the survey consists of seven dimensions named as equality, empathy, moral intelligence, justice, tolerance, self-control, and politeness ${ }^{4}$.

\subsection{Statistical methods used in data analyses:} Frequency analysis was used for socio-demographic data analysis, and chi-square tests were used for comparison of socio-demographic data. Normality testing was conducted to determine whether there was a difference between the groups. As the groups did not show normal distribution, non-parametric Mann-Whitney $U$ and Kruskal-Wallis tests were used to determine the difference between the groups.

\section{Findings}

Distribution of the participants by socio-demographic characteristics

Table 1 presents the distribution of socio-demographic characteristics of healthcare professionals that participated in this study.

The data in Table- 1 show that the average age of healthcare professionals was $36,44 \pm 9.52$. Furthermore, $65,5 \%$ of the participants were women, and $34,5 \%$ were men; $68,2 \%$ were married, and $31,8 \%$ were single or divorced; $61.5 \%$ had children while $38.5 \%$ did not.

Table 2 indicates that the participants attached great importance to the factor of equality. Fur-

\footnotetext{
${ }^{4}$ Permission was received from the Board of Ethics for Nonpharmacological Clinical Research in the Faculty of Medicine at Eskisehir Osmangazi University (July, 22, 2015 80558721/G-25). Written informed Consent of the participants was taken.
}

thermore, empathy, moral intelligence, justice, tolerance, self-control and politeness were also important for the healthcare professionals.

Mann-Whitney U Test Results for the "Survey for Measuring Moral Intelligence in the Provision of Healthcare Services"

Mann-Whitney U test was used to compare two independent groups, i.e. groups determined according to socio-demographic characteristics of the participants, with a view to seeing whether there was any difference between the groups regarding each dimension of the survey.

The distribution of female and male participants' factor scores was tested at 5\% significance level, and no significant difference was found between women and men with regard to factor scores $(\mathrm{p}>0,05)($ Table-3)

Having children was a factor that affected only the sub-scale of equality $(p<0,05)$. The mean ranks indicated that the participants with children had higher scores than the participants without children (Table-3).

There was a significant difference between the participants employed in the public sector and the private sector with regard to equality and justice $(p<0,05)$. The mean ranks showed that those working in the private sector had higher scores than those in the public sector (Table-3).

Test statistics results showed that there was no difference with regard to factor scores between the participants who had a family member receiving continuous healthcare and who did not have such a family member( $>0,05)$ ( Table-3).

\section{Variance analysis results for the "Survey for Measuring Moral Intelligence in the Provision of Healthcare Services"}

Kruskal-Wallis variance analysis was used compare more than two independent groups, i.e. groups determined according to socio-demographic characteristics of the participants, with a view to seeing whether there was any difference between the groups regarding each dimension of the survey. 
Paired comparisons were conducted for the factors that differed significantly by demographic characteristics of the participants.

In paired comparisons, the rank score of the group $\mathrm{i}$ is $\bar{R}_{i}$, and the rank score of the group $\mathrm{j}$ is $\bar{R}_{j}$. Thus, if the following equation is obtained, there is a difference between the groups $\mathrm{i}$ and $\mathrm{j}$. Otherwise, there is no difference between the groups.

$$
\begin{aligned}
& \sigma_{\bar{R}_{i}-\bar{R}_{j}}=\sqrt{\left(\frac{N(N+1)}{12}\left(\frac{1}{n_{i}}+\frac{1}{n_{j}}\right)\right)} \\
& \frac{\left|\overline{R_{i}}-\overline{R_{j}}\right|}{\sigma_{\overline{R_{i}}-\overline{R_{j}}}}>\sqrt{\chi_{\alpha ;(k-1)}^{2}}
\end{aligned}
$$

The results suggested that marital status of the participants had significant effects on their responses with regard to equality $(\mathrm{p}<0,05)$, moral intelligence $(\mathrm{p}<0,05)$, and justice $(\mathrm{p}<0,05)(13,14)$. Paired comparisons were conducted to test which marital statuses caused the significant difference with regard to equality, moral intelligence and justice (Table-4)

Test statistics regarding the relationship between marital status and equality showed that "singlemarried" and "single-divorced" groups had a significant effect on the difference $(\mathrm{p}<0,05)$. Test statistics regarding the relationship between marital status and moral intelligence showed that "single-divorced" and "married-divorced" individuals caused the difference $(p<0,05)$. There was a significant difference in factor scores of justice only between "married" and "divorced" individuals $(\mathrm{p}<0,05)($ Table-4)

Table-4 indicates that there was a significant difference in empathy between income level groups $(p<0,05)$. The difference derives from the factor scores of the participants with "high" and "low" income $(\mathrm{p}<0,05)$.

Table- 4 further suggests that there was a significant difference in the perception of equality between the groups defined according to working hours $(\mathrm{p}<0,05)$. However, paired comparisons did not show which groups caused the difference. There was also a significant difference with regard to politeness between the groups defined according to working hours $(\mathrm{p}<0,05)$. The difference resulted from the factor scores of healthcare professionals working " 8 hours" and "10 hours" per day $(\mathrm{p}<0,05)$.

Moreover, there was a significant difference in equality scores between the groups defined according to the frequency of working outside normal working hours $(p<0,05)$. This resulted from the difference between " 1 time- 5 times", " 3 timesnone" and "4 times-none" groups $(\mathrm{p}<0,05)(\mathrm{Ta}-$ ble-4).

The table- 4 also shows that there was a significant difference in equality scores between the age groups $(\mathrm{p}<0,05)$, and that the difference derived from the difference between "15-29 age group-45-59 age group" and "30-44 age group-45-59 age group" $(\mathrm{p}<0,05)$.

\section{Discussion and conclusion}

A good many of studies on intelligence reveal the correlation between leadership and intelligence $(2,15-17)$.In workplaces, individuals with greater moral awareness have developed better skills to create an ethical climate and to use cognitive and behavioral intelligence more positively than other employees(3).

Healthcare professionals frequently have to go through a "moral decision-making" process before getting engaged in a moral act in the diagnosis, treatment and care of patients. Managing this process effectively enables them to take the right actions for the diagnosis, treatment and care of patients. It is expected from healthcare professionals to be equipped with methodology required to choose the right in the moral decision-making process $(2,18)$.

There is a need to determine the methodology for moral decision-making and then to make healthcare professionals develop awareness of moral acts and comprehend how to act morally in daily healthcare practices. Healthcare providers frequently need to make quick decisions in the hectic work schedule. Because of the nature of the 
profession, they are expected to make the right decision at the right time with the awareness of ethical responsibilities.

Considering that the number of studies on moral intelligence is few, the discussions related to demographic data are based on previous research findings about not only moral intelligence but also its parameters-empathy, respect, justice, tolerance, politeness, self-control, conscience, and equality.

In the present study, the average age of the healthcare professionals ( $\mathrm{n}=789$ ) was $36,44 \pm 9,52$. Some results are comparable(19-21) while some are different from the average age found in this study(22).

In this research, $517(65,5 \%)$ healthcare professionals were women, and $272(34,5 \%)$ were men. In comparable studies, the number of female professionals were higher than the number of $\operatorname{men}(3,23-26)$.

In this research, $538(68.2 \%)$ healthcare professionals were married. In the literature, there are studies supporting our findings(3) as well as studies whose results are not consistent with $\operatorname{ours}(27)$.

In this study, $485(61,5 \%)$ of the participants had children. $552(70,0 \%)$ reported that their level of income was middle, high or very high. These rates are consistent with findings of similar studies related to having children and level of income(3,27-32). The participants of this study were either employed in Eskişehir in the public sector $(653,[82,8 \%])$ or in the private sector $(136$, $17,2 \%)$. The distribution of the participants by the public and the private sector is consistent with the findings of Korkmaz, Yağbasan et al. and Yavuz(33-35), but is inconsistent with Işik et al.(36). With regard to the participants' length of work experience, our findings are consistent with those of Işik, Korkmaz, Hasan Gül, and Bağci (32,33,37,38), but inconsistent with those of Kahriman et al.(28).

In this study, 469 (59,5\%) healthcare professionals were working less than ten hours per day while the remaining $320(40,5 \%)$ professionals were working 10 hours or more per day. With regard to the participants' daily working hours, our findings are consistent with the findings of Kahriman et al. and Çelen et al., but different from the findings of İlhan et al. and Ünal et al. $(28,39,40)$.

In the present study, $341(43,2 \%)$ professionals reported that they did not work outside normal working hours while the frequency of on-call work was up to four times a week in 448 (56,8\%) professionals. The nature of profession frequently requires healthcare providers to work long hours during the day and outside of normal working hours. In their study on the effects of on-call work on cognitive functions of residents, Kaya et al. revealed that on-call work increased depressive feelings among residents, causing anxiety disorder and attention deficit(41). The results of our study suggest that the frequency of on-call work is likely to stunt moral intelligence and related skills.

In this study, $268(34,0 \%)$ healthcare professionals had a family member receiving continuous healthcare in a hospital. Satisfaction of patients that receive continuous healthcare services is of particular importance for medical outcomes. An illness changes the lives of family members and other care providers, as well as the patient $(42,43)$. Thus, in this study it was expected that healthcare professionals with such experience would be more empathetic, fair and polite towards patients.

According to our research findings, the mean and the Cronbach's alpha for the equality factor were quite high, i.e. 4,46 and 0,922. The mean and the Cronbach's alpha values were respectively 4,42 and 0,858 for justice, 4,27 and 0,910 for empathy, 4,19 and 0,840 for self-control, 4,18 and 0,799 for tolerance, 4,18 and 0,722 for politeness, and 4,08 and 0,874 for moral intelligence.

In Mccomas et al. and Tüfekçi et al. studies on perception of justice, the mean scores and the Cronbach's alpha values of questions related to equality were comparable with the results in our study. With regard to the mean and the Cronbach's alpha value of justice, moral intelligence and tolerance, our results are consistent with the findings of previous studies $(44,45)$. With respect to empathy, our findings are consistent with those of Es et al., but different from those of Loureiro et al. 
The internal consistency regarding empathy was high in our study(44-51).

With respect to politeness, our findings are consistent with those of Basim et al.(52), but different from those of Mccomas et al.(44). The internal consistency regarding politeness was high in our study.

In the present study, with regard to equality, empathy, justice, moral intelligence, tolerance, politeness and self-control, there was no difference by gender $(p>0,05)$. The participants' approach to ethical problems and values may vary in some situations. It is known that, today, ethical problems have been increasing in work environments. In Örselli's study(16) there was no difference in responses by gender with regard to the role of factors such as honesty, impartiality and equality, prestige, trust and non-profit, and responsibility that support the ethical decision-making process. Akbaba et al. focused on the effect of gender on ethical decision-making, and found out that gender did not play a significant role in this process. Our findings are compatible with this studies (53).

The variable of "having children" caused a statistical difference only in the equality factor $(p<0,05)$. The difference was not statistically significant with regard to other factorss. With regard to the effect of having children on the dimension of empathy $(p>0,05)$, our results were consistent with those of Kahriman et $\mathrm{al}(28)$ and different from those of Özcan's study on empathy skills of nurses. Comparable with our results, previous studies didn't show any relationship between having children and the perception of distributive justice and equality(32).

In the present study, the scores of private sector employees were higher than the scores of public sector employees with regard to equality and justice. Organizational justice and equality are expected in healthcare services. Studies showed that working in an equal and just organizational culture increases employees' motivation(54). Inequality cause significant problems in healthcare provision. Compared to the public sector, private sector is a work environment where competition is heavier, there is less job security and economic concerns are greater(54-56). Private sector em- ployees are generally paid better; however, they work under heavier conditions in terms of working hours and workload. In the present study, it was found out that private sector employees gave more importance to justice and equality - a result that might be linked to their working conditions. Our research findings are consistent with findings in the literature(32-34).

The present study reveals a significant relationship between working in the private sector and the concepts of justice and equality. Fair and equal treatment is of particular importance for job satisfaction. If they notice that the treatment is not equal, their job satisfaction is likely to reduce. As public employees are accountable to the state and the hierarchy is less inflexible in the public sector, managers in this sector are less tolerant and less inclined to show respect and kindness and to treat equally. The findings reported in the literature are consistent with our findings(57-60).

In the present study, there was no statistically significant difference between the group that had a family member receiving continuous treatment and the group without such a family member with all factors $(\mathrm{p}>0,05)$.

Ozdemir et al. also found that the presence of any illness in the family did not have any effect on empathy(61). An illness or disorder causes people to lead a new life. Illness leads to changes in life standards of not only the patient but also their family members and friends(62). Thus, it was expected in this study that the participants' responses would be different if they had a family member living with an illness. However, we did not get the expected results probably because only a small proportion of the healthcare professionals that participated in this study had family members receiving continuous healthcare services. Individuals with leadership capacity may have positive traits and use these traits in professional life without the need to identify themselves with others.

Our results indicated that marital status had effects on equality $(\mathrm{p}<0,05)$, moral intelligence $(p<0,05)$, and justice $(p<0,05)$. Shapiro et al. reported in their study with 28 participants that patients expected physicians to be polite, friendly 
and respectful. At the end of the study, they listened to patients' experiences and found that all patients expected politeness, friendliness and respect regardless of age, marital status and cultural background. With regard to equality, our results revealed that individuals putting themselves on an equal footing to others associated equality with parameters such as respect, conscience and intelligence. The high rate of equality expectation reported in our study is consistent with Shapiro et al. results, i. e. patients expecting respect, friendliness and politeness from healthcare professionals and expecting to see themselves on an equal footing to healthcare providers. These findings are important in that they not only refer to equality in terms of rights but also bring about a broader definition of equality encompassing respect, politeness and conscience in the field of healthcare provision(63).

Several studies reported that the relationship between parameters of moral intelligence and marital status was not statistically significant. This is comparable with the findings of our study (64).

In the present study, the difference between marital status groups was significant with regard to the parameter of justice $(\mathrm{p}<0,05)$. This is consistent with findings of some studies and inconsistent with findings of some others $(65,66)$. Employees' expectations from their organizations generally concentrate on justice, equality and respect $(54,67)$. These findings support the high mean and percentile scores of equality, moral intelligence and justice in our study.

Our research findings further suggested that the difference between income level groups was significant with regard to the factor of empathy $(\mathrm{p}<0,05)$. A healthcare professional who is familiar with and aware of patients' feelings and who is able to make patients feel this awareness is more likely to build an effective communication with patients $(68,69)$. Several studies acknowledge that good communications skill is an important factor in ensuring patients' adherence to treatment. Unlike our results, some studies revealed no correlation between income level and empathy $(61,70)$.

The present study showed that the difference between groups based on the length of experience was significant with regard to the factor of equality $(p<0,05)$. In the literature, there is a consensus on the importance of providing healthcare services to all people under equal conditions regardless of religion, language, age, gender and level of income. The studies further highlight that healthcare providers are expected to be highly sensitive about differences between human beings, and that employees that have developed this sensitivity are less inclined to personal aggression $(71,72)$.

Daily working hours play a significant role in the politeness factor $(\mathrm{p}<0,05)$. People that are influenced by others' decisions and actions, give importance to others' opinions, protect their colleagues' rights and adopt a constructive approach to emerging problems serve as a model for creating a politeness culture in the workplace(73). Ann Gallagher indicates that spending extra time for someone is politeness and that this attitude has a positive effect on every person(74). It is important to ensure that healthcare professionals work under normal conditions to motivate them to develop awareness of the importance of politeness and to build a culture based on politeness in healthcare organizations(75). As politeness is a factor contributing to recovery, it needs to be a functioning component of healthcare provi$\operatorname{sion}(76)$. Wiesing's study highlighted that favorable working hours contributed to building a more harmonious communication between patients and healthcare professionals and hence to providing more qualified healthcare services(77).

The present study also revealed a significant relationship between on-call work and the equality factor $(p<0,05)$. The regulation on the Management of Inpatient Healthcare Facilities, updated on $20 / 01 / 2016$, specifies the rules and procedures regarding working outside normal working hours, i. e. on-call work for healthcare providers. It is important that a hospital management distributes on-call work equally and fairly among employees. In our study, the presence of a relationship between on-call work and perception of equality points to the need for adopting more effective policies regarding working outside normal working hours in the healthcare sector(78).

This study also showed a difference between age groups with regard to the perception of equali- 
ty $(\mathrm{p}<0,05)(79-81)$. The results of some studies are comparable with ours while some others are $\operatorname{not}(3,82-84)$.

Moral intelligence is an ethical leadership trait. Leadership traits comprise innate as well as acquired characteristics. People with leadership traits speak clearly, treat fairly and equally to all employees, build empathy, are respectful, conscientious, polite and tolerant, use self-control skills, are always aware of their behaviors and able to change their behaviors in a work environment. These leaders are respectful to rights of all stakeholders(85).

The results of our study suggest that healthcare professionals give importance to showing respect to patients, empathy is an important factor in healthcare communication and plays a facilitating role in getting information about patients, mental acceptance is required to achieve the goals in future plans, healthcare services are based on trust, patients need to trust healthcare professionals, and healthcare professionals are sensitive about trust from an ethical perspective. Almost all volunteers that participated in this study had self-respect, believed that they were able to think rationally, and paid attention to conscientious assessment of a "good" behavior.

The relationship between healthcare professionals and patients is asymmetrical. Our results show that healthcare professionals uphold respect for all people, patients and themselves, tend to see all people and patients on an equal footing to themselves and they expect respect from all other people, and believe every person worthy of respect.

Healthcare professionals' responses further indicate that they support patients' individuality, tend not to make any discrimination between patients, and treat fairly to all patients. Healthcare professionals that participated in our study were aware that discrimination based on individual differences is likely to jeopardize patients' individuality and right to access healthcare services.

Healthcare professionals agree that moral values are of particular importance in healthcare service provision. This shows that healthcare profes- sionals need moral values as well as universally accepted ethical values in their working environment.

Moral intelligence and its parameters are related to mental decision-making capacity used before getting engaged in a moral act. Moral intelligence helps physicians, nurses and patients, who are in a sort of ethical relationship in healthcare service provision, to build effective communication. An act based on moral intelligence capacity plays a facilitating role in the relationship between healthcare professionals and patients, and reduces problems among healthcare professionals. Effective communication also helps healthcare professionals to solve communication problems arising from gender, age, culture, experience, position and inequality.

\section{After our work}

What the moral Intelligence is and what benefits it can provide to those who have leadership qualifications must be revealed by the experts of the subject. In addition, training should be provided to increase the awareness and awareness of health professionals, and trainings should be increased in order to provide needs with a critical perspective.

It is thought that it would be appropriate to create special areas in order to ensure the applicability of "Moral Intelligence and parameters" for all healthcare professionals in hospitals.

All of the authors declare that they have all participated in the design, execution, and analysis of the paper, and that they have approved the final version. Additionally, there are no conflicts of interest in connection with this paper, and the material described is not under publication or consideration for publication Acta Bioethica.

\section{Acknowledgments}

This study was supported by Osmangazi University Research Foundation, Grant Number: 2015914. We would like to thank all the doctors and nurses for their excelent cooperation. 


\begin{tabular}{|c|c|c|c|}
\hline & & \multicolumn{2}{|c|}{ Physicians and Nurses } \\
\hline & & \multicolumn{2}{|c|}{ Mean: $36,44 \pm 9,52$} \\
\hline & & Number & Percentage \\
\hline \multirow[t]{2}{*}{ Gender } & Female & 517 & $65,5 \%$ \\
\hline & Male & 272 & $34, .5 \%$ \\
\hline \multirow[t]{3}{*}{ Marital Status } & Single & 216 & $27,4 \%$ \\
\hline & Married & 538 & $68,2 \%$ \\
\hline & Divorced & 35 & $4,4 \%$ \\
\hline \multirow[t]{2}{*}{ Having Children } & Yes & 485 & $61,5 \%$ \\
\hline & No & 304 & $38,5 \%$ \\
\hline \multirow[t]{5}{*}{ Income Level } & Very high & 34 & $4,3 \%$ \\
\hline & High & 213 & $27,0 \%$ \\
\hline & Middle & 305 & $38,7 \%$ \\
\hline & Low & 201 & $25,5 \%$ \\
\hline & Very low & 36 & $4,6 \%$ \\
\hline \multirow{2}{*}{$\begin{array}{l}\text { Public vs. Private Sector } \\
\text { Employment }\end{array}$} & $\begin{array}{ll}\text { Public } & \text { Healthcare } \\
\text { Organization } & \\
\end{array}$ & 653 & $82,8 \%$ \\
\hline & $\begin{array}{ll}\text { Private } & \text { Healthcare } \\
\text { Organization } & \\
\end{array}$ & 136 & $17,2 \%$ \\
\hline \multirow[t]{5}{*}{ Length of Experience } & Less than 1 year & 56 & $7,1 \%$ \\
\hline & $1-5$ years & 182 & $23,1 \%$ \\
\hline & $6-10$ years & 114 & $14,4 \%$ \\
\hline & 11-20 years & 241 & $30,5 \%$ \\
\hline & More than 20 years & 196 & $24,8 \%$ \\
\hline \multirow{5}{*}{ Daily Working Hours } & 4 hours & 3 & $0,4 \%$ \\
\hline & 6 hours & 10 & $1,3 \%$ \\
\hline & 8 hours & 456 & $57,8 \%$ \\
\hline & 10 hours & 119 & $15,1 \%$ \\
\hline & More than 10 hours & 201 & $25,5 \%$ \\
\hline \multirow{5}{*}{$\begin{array}{l}\text { Weekly Frequency of } \\
\text { Working Outside Normal } \\
\text { Working Hours }\end{array}$} & 1 & 150 & $19,0 \%$ \\
\hline & 2 & 160 & $20,3 \%$ \\
\hline & 3 & 91 & $11,5 \%$ \\
\hline & 4 & 47 & $6,0 \%$ \\
\hline & None & 341 & $43,2 \%$ \\
\hline \multirow{2}{*}{$\begin{array}{l}\text { Presence of } \begin{array}{r}\text { Family } \\
\text { Members }\end{array} \\
\text { Receiving } \\
\text { Continuous } \\
\text { Healthcare }\end{array}$} & Yes & 268 & $34,0 \%$ \\
\hline & No & 521 & $66,0 \%$ \\
\hline
\end{tabular}

Table 1. Distribution of the participants by socio-demographic characteristics. 
Evaluation of Moral Intelligence of Healthcare Professionals - Hulya Ozturk, Omur Sayligil, Zeki Yildiz

\begin{tabular}{|l|l|l|}
\hline Sub-scales & $\begin{array}{l}\text { Mean } \\
\text { Standard Deviation }\end{array}$ & Cronbach's Alpha \\
\hline Equality & $4,46 \pm, 532$ & 0,922 \\
\hline Empathy & $4,27 \pm, 541$ & 0,910 \\
\hline Moral Intelligence & $4,08 \pm, 619$ & 0,874 \\
\hline Justice & $4,42 \pm, 554$ & 0,859 \\
\hline Tolerance & $4,18 \pm, 583$ & 0,799 \\
\hline Self-control & $4,19 \pm, 632$ & 0,840 \\
\hline Politeness & $4,18 \pm, 654$ & 0,772 \\
\hline
\end{tabular}

Table 2. Distribution of mean scores of sub-scales in the "Survey for Measuring Moral Intelligence in the Provision of Healthcare Services".

\begin{tabular}{|l|l|l|l|l|l|l|l|}
\hline $\mathrm{p}$ & Equality & Empathy & $\begin{array}{l}\text { Moral } \\
\text { Intelligence }\end{array}$ & Justice & Tolerance & $\begin{array}{l}\text { Self- } \\
\text { control }\end{array}$ & Politeness \\
\hline Gender & 0,246 & 0,380 & 0,061 & 0,871 & 0,612 & 0,235 & 0,745 \\
\hline Having Children & 0,025 & 0,403 & 0,140 & 0,055 & 0,096 & 0,612 & 0,154 \\
\hline $\begin{array}{l}\text { Public vs. } \\
\text { Private Sector } \\
\text { Employment }\end{array}$ & 0,001 & 0,337 & 0,124 & 0,026 & 0,174 & 0,698 & 0,785 \\
\hline $\begin{array}{l}\text { Presence of } \\
\text { Family Members } \\
\text { Receiving } \\
\begin{array}{l}\text { Continuous } \\
\text { Healthcare }\end{array}\end{array}$ & 0,283 & 0,560 & 0,196 & 0,462 & 0,946 & 0,958 & 0,126 \\
\hline
\end{tabular}

Table 3. Mann-Whitney U test results for sub-scales of the "Survey for Measuring Moral Intelligence in the Provision of Healthcare Services"

\begin{tabular}{|l|l|l|l|l|l|l|l|}
\hline $\mathrm{p}$ & Equality & Empathy & $\begin{array}{l}\text { Moral } \\
\text { Intelligence }\end{array}$ & Justice & Tolerance & $\begin{array}{l}\text { Self- } \\
\text { control }\end{array}$ & Politeness \\
\hline Marital Status & 0,007 & 0,881 & 0,011 & 0,034 & 0,456 & 0,118 & 0,586 \\
\hline Income Level & 0,368 & 0,014 & 0,783 & 0,619 & 0,720 & 0,362 & 0,155 \\
\hline $\begin{array}{l}\text { Length of } \\
\text { Experience }\end{array}$ & 0,037 & 0,445 & 0,141 & 0,245 & 0,855 & 0,116 & 0,929 \\
\hline $\begin{array}{l}\text { Daily Working } \\
\text { Hours }\end{array}$ & 0,523 & 0,534 & 0,253 & 0,139 & 0,306 & 0,316 & 0,007 \\
\hline $\begin{array}{l}\text { Frequency of } \\
\begin{array}{l}\text { Working Outside } \\
\text { Normal Working } \\
\text { Hours }\end{array}\end{array}$ & 0,000 & 0,456 & 0,400 & 0,230 & 0,628 & 0,928 & 0,784 \\
\hline Age Groups & 0,002 & 0,813 & 0,457 & 0,207 & 0,271 & 0,299 & 0,657 \\
\hline
\end{tabular}

Table 4. Kruskal-Wallis test results for sub-scales of the "Survey for Measuring Moral Intelligence in the Provision of Healthcare Services". 


\section{References}

1. Cakar U, Arbak Y. Modern Yaklaşimlar Işiğinda Değişen Duygu-Zekâ İlişkisi Ve Duygusal Zekâ. DEUSBED 2004; 6(3): 1-26.

2. Lennick D, Kiel F. Moral Intelligence: Enhancing Business Performance and Leadership Success FT Press. Pearson Prentice Hall; 2007: 1-336.

3. Kruger T. Moral Intelligence: The Construct and Key Correlates. Thesis: University of Johannesburg 2012; 1-298.

4. Borba M. 2001. Building moral intelligence: the seven essential virtues that teach kids to do the right thing. Vol.192. San Francisco.

5. Di Pippo AF. The Concept of Poiesis in Heidegger's. An Introduction to Metaphysics. Paper presented at the Thinking Fundamentals. IWM Junior Visiting Fellows Conferences; 2000.

6. Birliği DH. Tip etiği el kitabi. (M. Civaner Trans.) Fransa; 2005.

7. Yildiz et al. Çok Değişkenli İstatistiklerle Tüketicilerin Sivi Yağ Ambalaj Tercihlerine Göre Bölümlendirilmesi. Dumlupinar University Journal of Social Science 2012; 1(32): 1-11.

8. Lawshe CH. A Quantitative Approach to Content Validity. Personnel Psychology 1975; 28(4): 563-75.

9. Allahyari et al. Development and Evaluation of a New Questionnaire for Rating of Cognitive Failures at Work. International Journal of Occupational Hygiene 2011; 3(1): 6-11.

10. Büyüköztürk S. Sosyal Bilimler İçin Veri Analizi El Kitabi. Ankara: Pegem; 2017: 1-216.

11. Cetin B, Doğan T, Sapmaz F. The Turkish Adaptation of Brief Fear of Negative Evaluation Scale: The Validity and Reliability. Study Education \& Science 2010; 35(156): 205-17.

12. Sandal M. Factor Analysis for Level of Ordinal Measurement and an Application. Master of Science Thesis. Eskisehir: ESOGU Department of Statistics; 2015: 1-77.

13. Schumacker RE, Lomax RG. A Beginner's Guide to Structural Equation Modeling. London: Psychology Press; 2004: $1-510$.

14. Gamgam H, Altunkaynak B. Parametrik Olmayan Yöntemler. Seçkin: Ankara; 2012.

15. Martin DE, Austin B. Validation of the Moral Competency Inventory Measurement Instrument: Content, Construct, Convergent and Discriminant Approaches. Management Research Review 2010; 33(5): 437-45.

16. Orselli E. 2010. Türkiye’ de Toplumsal Ve Yönetsel Etik Değerler İle İkilemler: Uygulamali Bir Çalişma. Selçuk Üniversitesi Sosyal Bilimler Enstitüsü; 2010.

17. Sahin F. The Relationship between Creativity and Intelligence: New Evidence. Elementary Education Online 2014; 13(4): 1516-30.

18. Ghosh A. Understanding Medical Uncertainty: A Primer For Physicians. JAPI 2004; (52): 739-742.

19. Seşen H. Adalet Algisinin Tükenmişliğe Etkisi: İş Tatmininin Araci Değişken Rolünün Yapisal Eşitlik Modeli İle Testi. Savunma Bilimleri Dergisi 2010; 9(2): 67-90.

20. Jonas E, Maier GW, Kissling W, Hamann J. Is Interpersonal Fairness In The Doctor-Patient Relationship Associated With Long-Term Compliance In Patients With Schizophrenia? Psychology 2013; 4(06): 45.

21. Kadioğlu et al. Ethical Problems in Geriatrics: Views of Turkish Primary Healthcare Pro-fessionals. Geriatrics \& Gerontology International 2013; 13(4): 1059-1068.

22. Faramarzi $\mathrm{M}$ et al. The Role of Moral Intelligence and Identity Styles in Prediction of Mental Health Problems in Healthcare Students. Health 2014; 6(08): 664.

23. Akbari A. Investigation of Moral Intelligence principles and Knowledge Management Dimensions Relationship with Organizational Learning from Teachers' Viewpoint. RRAMT 2013; 38(2): 94-102.

24. Razavian SA, Islami HDDAH. Effect of moral intelligence on customer satisfaction: A study on yazd customs officials and customers. Indian J. Sci. Res 2014; 4(6): 68-6.

25. Hossein et al. Innovative organizational climate, moral intelligence and attitude toward change. MAGNT Research Report 2014; 3(2): 527-535.

26. Najafian et al. Exploring the relationship between moral intelligence and achievement motivation among academic professors of Iran universities. International Journal of Management and Humanity Sciences 2014; 3(9): 3023-30.

27. Morrison et al. Empathy for positive and negative emotions in social anxiety disorder. Behaviour research and therapy 2016; (87): 232-242.

28. Kahriman et al. The effect of empathy training on the empathic skills of nurses. Iranian Red Crescent Medical Journal 2016; 18(6): 1-11. 
29. Ozcan H. Hemşirelerin Empatik Eğilim Ve Empatik Becerileri: Gümüşhane Örneği. Gümüşhane Üniversitesi Sağlik Bilimleri Dergisi 2012; 1(2): 1-9.

30. Budak G, Sürgevil O. Tükenmişlik Ve Tükenmişliği Etkileyen Örgütsel Faktörlerin Analizine İlişkin Akademik Personel Üzerinde Bir Uygulama. DEUIIBFD 2013; 20(2): 1-12.

31. Beyazsaçli MS, Bulut N. Devlet Hastanelerinde Görev Yapan Hemşirelerin İs Doyum Düzeylerinin Incelenmesi. Paper presented at the International Conference On New Trends İn Education and Their Implications, 1-13 November, 2010.

32. Işik ÖG. Duygusal Tükenmişlik ve Kurumsal Adalet İlişkisi: Özel Bir Hastanede Görev Yapan Hemşireler Üzerine Bir Araştirma. Intermedia International e-Journal 2016; 2(3): 372-91.

33. Korkmaz S. Hastanelerde Doktor, Hemşire ve Ebelerin Motivasyonunu Etkileyen Faktörler Bir Uygulama. (Master Thesis). Çağ Üniversitesi, Sosyal Bilimler Enstitüsü. İçel; 2008.

34. Yağbasan M, Çakar F. Doktor-Hasta İlişkisinde Dile ve Davranişa Dayali İletişimsel Sorunlari Belirlemeye Yönelik Bir Alan Araştirmasi. SUSBED 2008; (15): 609-29.

35. Yavuz E. Kamu Ve Özel Sektör Çalişanlarinin Örgütsel Adalet Algilamalari Üzerine Bir Karşilaştirma Çalişmasi. Doğuş Üniversitesi Dergisi 2011; 11(2): 302-12.

36. Işik O, Uğurluoğlu O, Akbolat M. Sağlik Kuruluşlarinda Örgütsel Adalet Algilarinin Örgütsel Bağliliğa Etkisi. Doğus Universitesi Dergisi 2012; 13(2): 1-8.

37. Ince HG. Etik Liderlik ve Örgütsel Adalet Arasindaki İlişkiler Üzerine Bir Araştirma. Ömer Halisdemir Üniversitesi İktisadi ve İdari Bilimler Fakültesi Dergisi 2014; 7(2): 1-13.

38. Bağci Z.Hemşirelerin Örgütsel Adalet Algilarinin İş Tatminleri Üzerindeki Etkisini İncelemeye Yönelik Bir Araştirma. Pamukkale University Journal of Social Sciences Institute 2016; (25): 1-9.

39. Celen et al. Ankara Onkoloji Eğitim Hastanesinde Çalişanlarin İş Doyumu. Hacettepe Sağlik İdaresi Dergisi 2004; 7(3): $1-8$.

40. Unal S, Karlidağ R, Yoloğlu S. Hekimlerde Tükenmişlik Ve İş Doyumu Düzeylerinin Yaşam Doyumu Düzeyleri İle İlişkisi. Klinik Psikiyatri 2001; 4(2): 113-18.

41. Yavaşcaoğlu et al. Anestezi Asistanlarinda Nöbetin Bilişsel İşlevler Ve Ruhsal Durum Üzerine Etkisi. Uludă̆ Üniversitesi Tip Fakültesi Dergisi 2007; 33(2): 75-79.

42. Onsüz MF et al. İstanbul'da Bir Tip Fakültesi Hastanesinde Yatan Hastalarin Memnuniyet Düzeyi. Marmara Medical Journal 2008; 21(1): 33-49.

43. Hiçdurmaz D, İnci FA. Eşduyum Yorgunluğu: Tanimi, Nedenleri Ve Önlenmesi. Psikiyatride Güncel Yaklaşimlar 2015; 7(3): 295-303.

44. McComas et. al. Individuals' Willingness to Talk To Their Doctors About Clinical Trial Enrollment. Journal of Health Communication 2010; 15(2): 189-204.

45. Tüfekci N, Asiğbulmuş H. The Factors that Effective in the Choice of Hospital and Patient Satisfaction: The Sample of Isparta. Journal of Current Researches on Health Sector 2016; 6(2): 1-11.

46. Heponiemi et al. The effects of ownership, staffing level and organizational justice on nurse commitment, involvement, and satisfaction: a questionnaire study. International Journal of Nursing Studies 2011; 48(12): 1551-1561.

47. Gillet et al. The Mediating Role of Organizational Justice In The Relationship Between Transformational Leadership And Nurses' Quality Of Work Life: A Cross-Sectional Questionnaire Survey. International Journal of Nursing Studies 2013; 50(10): 1359-67.

48. Mottaghi M. et al. The Relationship Between the Leadership Styles and Moral Intelligence. Bulletin of Environment. Pharmacology and Life Sciences 2014; 3(Special Issue II): 429-433.

49. Moghadas M. Investigate of Relationship Between Moral Intelligence and Distress Tolerance in Isfahan Staff. International Journal 2013; 2(2): 2307-37.

50. Martin DE, Austin B. Validation of The Moral Competency Inventory Measurement Instrument: Content, Construct, Convergent and Discriminant Approaches. Management Research Review 2012; 33(5): 437-51.

51. Hosseinia et al. The Effect of Managers' Moral Intelligence on Business Performance. International Journal of Organizational Leadership 2013; 2(2): 62-71.

52. Basim HN, Seşen H. Kontrol Odağinin Çalişanlarin Nezaket Ve Yardim Etme Davranişlarina Etkisi Kamu Sektöründe Bir Araştirma. Selçuk Üniversitesi Sosyal Bilimler Enstitüsü Dergisi 2006; (16): 159-168.

53. Akbaba A, Erenler E. Etik Karar Verme Ve Cinsiyet Farkliliklari Üzerine Bir Araştirma. Dumlupinar Üniversitesi Sosyal Bilimler Dergisi 2011; 31: 247-264.

54. Mathabad et al. Organizational Justice and the Shortage of Nurses in Medical \& Educational Hospitals, in Ur- 
mia-2014. Global Journal of Health Science 2016; 8(2): 99.

55. Morrow MR. Fairness and Justice in Leading-Following: Opportunities to Foster Integrity in the First 100 Days. Nursing Science Quarterly 2012; 25(2): 188-93.

56. Puschel K, Furlan E, Dekkers W. Social Health Disparities in Clinical Care: A New Approach to Medical Fairness. Public Health Ethics 2017; 10(1): 78-85.

57. Eğinli AT. Çalişanlarda İş Doyumu: Kamu Ve Özel Sektör Çalişanlarinin İş Doyumuna Yönelik Bir Araştirma. Atatürk Üniversitesi İktisadi ve İdari Bilimler Dergisi 2009; 23(3): 1-9.

58. Yavuz E. Kamu Ve Özel Sektör Çalişanlarinin Örgütsel Adalet Algilamalari Üzerine Bir Karşilaştirma Çalişmasi. Doğuş Üniversitesi Dergisi 2011; 11(2): 302-312.

59. Turhan MK. Kamu Görevlileri Bakimindan İşyerinde Psikolojik Taciz (Mobbing) ve Hukuki Korunma Yollari. Journal of Work and Organizational Psychology 1996; 5(2): 167.

60. Harun K.Kamu ve Özel Sektör Kuruluşlarinin Örgütsel Kültürünün Analizi ve Kurum Kültürünün Çalişanlarin Örgütsel Bağliliğina Etkisi. Maliye Dergisi 2008;135-70.

61. Ozdemir et al. Levels of empathy and its relations with job satisfaction among nurses in an University Hospital. Smyrna Tip Dergisi 2014; 30: 1-9.

62. Mete HE. Kronik Hastalik Ve Depresyon. Klinik Psikiyatri 2008; 11: 3-18.

63. Shapiro J, Mosqueda L, Botros D. A Caring Partnership: Expectations of ageing persons with disabilities for their primary care doctors. Family practice 2003; 20(6): 635-41.

64. Ozdemir AY. Ozdemir A.Duygusal Zeka Ve Çatişma Yönetimi Stratejileri Arasindaki İlişkilerin İncelenmesi: Üniversitede Çalişan Akademik Ve İdari Personel Üzerine Uygulama. Selçuk Üniversitesi Sosyal Bilimler Enstitüsü Dergisi 2007; (18): 393-410.

65. Başar U. Örgütsel Adalet Algisi, Örgütsel Özdeşleşme ve İş Tatmini Arasindaki İlişkilere Yönelik Görgül Bir Araştirma. (Master Thesis), Kara Harp Okulu, Savunma Bilimleri Enstitüsü; 2011.

66. Akduman, G, Yüksekbilgili Z, Hatipoğlu Z. Medeni Durumuna Göre Örgütsel Adalet Algisi. Uluslararasi Akademik Yönetim Bilimleri Dergisi 2015; 1(1): 1-9.

67. Rafii F, Nasrabadi AN, Forooshani ZSD. Expectation of Fairness: A turning point in the professional satisfaction of Iranian nurses. Electronic Physician 2016; 8(6): 2524.

68. Díez-Goñi N, Rodríguez-Díez M. Why teaching empathy is important for the medical degree. Revista Clínica Española 2017 (English Edition).

69. Fine VK, Therrien ME. Empathy in the doctor-patient relationship: skill training for medical students. Academic Medicine 1977; 52(9): 752-757.

70. Gülbahçe A. Rehberlik ve Psikolojik Danişmanlik Programini Tercih Edecek Olan Öğrencilerin Empatik Eğilim ve Empatik Becerilerinin Bazi Değişkenlere Göre İncelenmesi. AMUEFEBD 2016; 7(1): 1-15.

71. Tarhan M. et al. Bir Eğitim Araştirma Hastanesinde Çalişan Hemşirelerin Farkliliklara ve Farklilik İklimine Yönelik Algilarinin Belirlenmesi. Hemşirelikte Araştirma Geliştirme Dergisi 2016; 18(1): 1-13.

72. Sliter et al. Inching toward inclusiveness: diversity climate, interpersonal conflict and well-being in women nurses. Sex Roles 2014; 71(1-2): 43-54.

73. Karaman A, Aylan S. Örgütsel Vatandaşlik. Kahramanmaraş Sütçü İmam Üniversitesi İktisadi ve İdari Bilimler Fakültesi Dergisi 2012; 2(1): 35-48.

74. Gallagher A. Acknowledging small acts of kindness. Nursing Ethics 2012; 19(3): 311.

75. Buetow SA. Physician Kindness as Sincere Benevolence. Canadian Medical Association Journal 2013; 185(10): 928.

76. Health I. Kindness in healthcare: what goes around. In: British Medical Journal Publishing Group 2012.

77. Wiesing U. Ethical aspects of limiting residents'work hours. Bioethics 2007; 21(7): 398-405.

78. Yatakli Tedavi Kurumlari İşletme Yönetmeliği, Güncellenme Tarihi: 20/10/2016, Sağlik Bakanliği, Yayimlandiği R. Gazetenin Tarihi:13.1.1983, No 17927.

79. Deniz S, Cimen M, Ozsari H. Sağlik Kuruluşu Çalişanlarinin Örgütsel Adalet Algisini Belirlemeye Yönelik Bir Araştirma. International Journal of Social Science 2016; (42): 329-43.

80. Chaitoff et al. Associations between physician empathy, physician characteristics, and standardized measures of patient experience. Academic Medicine 2017.

81. Razavian SA, Islami HD. Effect of moral intelligence on customer satisfaction: a study on Yazd customs officials and customers. Indian J. Sci. Res 2014; 4(6): 681-686.

82. Sahin ZA, Ozdemir F. Hemşirelerin İletişim Ve Empati Beceri Düzeylerinin Belirlenmesi. Jaren 2015; 1(1): 1-7. 
83. Geller G, Tambor ES, Chase GA, Holtzman NA. Measuring physicians' tolerance for ambiguity and its relationship to their reported practices regarding genetic testing. Medical Care 1993; 989-1001.

84. Gerace A, Oster C, O'Kane D, Hayman CL, Muir-Cochrane E. Empathic processes during nurse-consumer conflict situations in psychiatric inpatient units: A qualitative study. International Journal of Mental Health Nursing 2016. Wiley Online Library.

85. Hasan G. Ince H. Etik Liderlik ve Örgütsel Adalet Arasindaki İlişkiler Üzerine Bir Araştirma. Ömer Halisdemir Üniversitesi İktisadi ve İdari Bilimler Fakültesi Dergisi 2014; 7(2): 1-11.

Received: July 2, 2020

Accepted: July 20, 2020 